\title{
Types of Paeonia and Their Use in Phytotherapy
}

\author{
Gülbahar DEMIRBOĞA ${ }^{1 *}$, Yasin DEMİRBOĞA ${ }^{2}$, Nusret ÖZBAY ${ }^{3}$
}

\begin{abstract}
Treatment with medicinal herbs dates back to the times before Christ and has been widely used all over the world for years. Today, its importance is increasing day by day and it is widely preferred because it is found more reliable. According to the World Health Organization, 20 thousand plant species are known in modern and traditional medicine. The number of plants used by the cosmetic and botanical industry is not included to the number. It takes many years to recognize a plant and use it in treatment and it is very difficult to protect it. Therefore, it is of great importance to recognize and develop the plants used in phytotherapy in the past. Paeonia L. (Paeoniaceae), known as "peony", is a perennial (geofit) plant with showy and attractive flowers and tubers under the ground. Paeoniaceae family is located in the rich flora of our country and has been used for their many medicinal effects. In this review article, peony species and their use in phytotherapy in Turkey and World were discussed with the studies on the subject.
\end{abstract}

Keywords: Paeonia, Peony, Phytotherapy, Geophyte

\section{Paeonia Türleri ve Fitoterapide Kullanımı}

\section{Öz}

Şifalı bitkilerle tedavi, milattan önceki zamanlara kadar uzanır ve yıllardır tüm dünyada yaygın olarak kullanılmaktadır. Günümüzde önemi gün geçtikçe artmakta ve daha güvenilir bulunduğu için yaygın olarak tercih edilmektedir. Dünya Sağlık Örgütü'ne göre modern ve geleneksel tıpta 20 bin bitki türü biliniyor. Kozmetik ve botanik endüstrisinin kullandığı bitki sayısı rakamlara dahil edilmemiştir. Bir bitkiyi tanımak ve tedavide kullanmak uzun yıllar alır ve onu korumak çok zordur. Bu nedenle geçmişte fitoterapide kullanılan bitkilerin tanınması ve geliştirilmesi büyük önem taşımaktadır. "Şakayık" olarak bilinen Paeonia L. (Paeoniaceae), yer altında gösterişli ve çekici çiçekleri ve yumruları olan çok yıllık (geofit) bir bitkidir. Paeoniaceae familyası, ülkemizin zengin florasında yer almakta ve birçok tıbbi etkisinden dolayı kullanılmaktadır. Bu derleme yazısında şakayık türleri ve Türkiye ve Dünya'daki fitoterapide kullanımları konu ile ilgili çalışmalarla tartışılmıştır.

Anahtar Kelimeler: Paeonia, Şakayık, Fitoterapi, Geofit

\footnotetext{
${ }^{1}$ Türkiye Milli Botanik Bahçesi Müdürlüğü, Ankara, Türkiye, demirbogagulbahar@gmail.com

${ }^{2}$ Türkiye Milli Botanik Bahçesi Müdürlüğ̈̈, Ankara, Türkiye, yasin.demirboga@gmail.com

${ }^{3}$ Bingöl Üniversitesi, Ziraat Fakültesi, Bingöl, Türkiye, nozbay@bingol.edu.tr
}

${ }^{1}$ https://orcid.org/0000-0002-5511-2785 ${ }^{2}$ https://orcid.org/0000-0001-5914-7806 ${ }^{3}$ https://orcid.org/0000-0001-9642-119X 


\section{Introduction}

Turkey is extremely rich in terms of plant diversity of a country. On the basis of this diversity, the presence of Turkey's on the three Phytogeographic regions, topographic diversity, diversity of climate and geological structure play role (Davis, 1965). While it was said that there were 3000-5000 species that grow naturally in Turkey until 1960, according to the studies and researches of the last 40 years, it has been revealed that this number is over 9000 today. Floristic studies in Turkey, especially in the 1700 s began with Tournefort. Later, the rich flora of our country was proved with the works of E. Boissier's "Flora of Turkey and East Aegean Islands", and these studies were tried to be completed with many floristic researches made after them. According to the result of this research in terms of species compared with the flora of Central and Western European countries, Turkey is much richer (Donner, 2007).

\section{Paeonia, Important Types}

Turkey; geographical regions with differences in climate and soil characteristics, the intersection of Asian and European continents, being located at the intersection of two important Vavilov gene centers (Mediterranean and Near East), being surrounded on three sides by seas, three important phytogeographic regions (Europe-Siberia, Iran-Turan and Mediterranean). It has an important place in the world in terms of plant diversity. With the last diagnosis, there are over 12000 plant taxa in our country (Avc1, 2005; Karagöz et al., 2010). The rate of endemism of plant diversity as in Turkey (34\%) in order to conserve has an important place in the world. Compared with Europe, which is 15 times larger than Turkey, that our wealth is better understood. As a matter of fact, while Greece has the most endemic species with 800 in Europe, this number is more than 3000 in Turkey (Uyanık, 2013). Twelve thousand endemic plant species grow in the world and most of these endemic plants grow in Anatolian lands. About a third, that is, four thousand. Considering that there are two thousand 400 endemic plant species throughout Europe, the value of our existence is better understood (Anonymous, 2020a). Due to the fact that Turkey has such a rich flora, geophytes show a great variety in the country. Turkey is known as more than 900 of geofits (bulbs, tubers, rhizomes) plant species (more than 1000 taxa) are (Kaya, 2016). Paeonia L. (Paeoniaceae) are perennial (geophyte) plants known as "peony”, with showy flowers and underground tubers (Ünlü, 2010). Paeonia species are also known as 'Ayıgülü, Eşek Gülü, Bocur, Şakayık, Yer Şakayığı, Dağ Zambağı, Savul, Ayı Kulağı, Kavak Gülü, Kozluk Çiçeği, Orak Gülü Tombak’ in Turkey (Baytop 1994, 1999; Tuzlac1, 2006; Tanker et al., 2007). The only herbaceous form of peony in our country; it is a perennial 
plant with tubers, blooms in different colors and can grow up to $1 \mathrm{~m}$. Herbaceous peony accepted as the major gene present in central Turkey Flora 11 taxa including 54 populations have been identified (Kaya, 2010) Researchers have shown that there are six species in our flora, but they are rare in nature, although tubers are exported (Baytop, 1994; Özhatay et al., 1998). Since the cultivation techniques are not known, the tubers exported are collected from nature especially the endemic-rare species are becoming extinct. Due to the insufficiency of studies on peonies; although we have the main gene center of peony, it could not be evaluated effectively because exactly how many species exist, in which regions, which species are in danger, breeding techniques and usage possibilities are not known; there was no contribution to the national economy. Up to now, all regions of Turkey have been scanned, and 54 populations have been identified and cultured from generally $500-2500 \mathrm{~m}$ high altitude and rocky places. Only Turkey fluorescent belonging $P$. turcica, unknown subspecies of $P$. xkayae species and other species are introduced at international level. Especially the distribution of $P$. peregrina species in many regions and population differences between these locations have been highlighted (Kaya, 2010).

\section{The Place and Importance of Phytotherapy in History}

The term "phytotheraphy; phytos= plant, therapy= treatment", which can be explained as the approach of treating patients by using herbs traditionally in China and India, was first used by the French physician Henri Lenclerc who lived between 1870-1953. It is named in the magazine called Presence Medical (Sarışen et al., 2005; Sert et al, 2015). In the inscriptions dating back to 3000 years B.C., it has been proved that in some civilizations there were treatments with herbal and animal drugs. Approximately B.C. in 2500 Rig Veda, one of the important representatives of Indian medicine, has been in a parallel development with the medicine in the Far East and mentioned about a thousand medicinal plants in his reports. However, in the writings of Hippocrates, who is an important name of Greek medicine and accepted as the father of modern medicine, he mentioned about 400 herbal products. During the period of Islamic civilization, Ebu Reyhan, the author of the book "Kitâbü's Saydana Fî't Tıb", a copy of which mentions about 20 medicinal plants, is in the Orhan Gazi Library, and mentioned 800 animal and herbal treatments that were accepted as reference books until the 1650s. Ibn-i Sina and Al Gafini, who wrote the book "Medicinel Law", have important works on herbal medicine. In addition, in 1978, a commission formed by Germany prepared a report evaluating the clinical effects of 300 herbs (Nathan et al., 1999; Izzo et al., 2005).

Nowadays, the use of natural products and medicinal plants is increasingly widespread for individuals to prevent and treat disease. Because these herbal products are easily accessible and cheap, and at the same time, the amount of use has increased among the people, considering that they 
are harmful to nature. Since it is natural and has no harmful effects, the consumption of many animal and herbal products, vitamins, minerals and similar substances has been increasing in recent years (Friedman, 2000; Izzo et al., 2005). According to the data of the World Health Organization, it is known that around 20 thousand plant species are used in modern and traditional types. Plant species used by the cosmetic and botanical industry are not included in this number. It was noted that in 2000 the medical and aromatic plants market share of approximately 60 billion dollars. This figure accounts for approximately 20 percent of the annual pharmaceutical market in the world. According to international reports, the global market for medicinal herbal products and medicines reached 93 billion dollars in 2015 and 107 billion dollars in 2017. The herbal products and medicines market has grown significantly over the past decade despite the economic recession worldwide. Despite the fact that Turkey is one of the most important countries, world exports of medicinal and aromatic plants in terms of medicinal and aromatic plants are not yet at the desired level. According to data of 2017 in Turkey, about 140 million dollars in the vicinities medicinal and aromatic plants performing export market has found a total of 2.5 billion dollars. Turkey exports of medicinal plants which ranks $18^{\mathrm{h}}$ of 110 countries (Anonymous, 2018).

\section{Its Use in Phytotherapy and Its Chemical Content}

Paeonia flowers (Flores paeoniae) contain anthocyanin pigments (paeonin), flavonoids (chempferol derivatives), tannins (gallottanene, which has been proven in leaves and roots). It has been used in folk medicine in the past to treat epilepsy, rheumatism, intestinal disorders (especially seeds and roots) and cough. It has been used in homeopathy against cracks, hemorrhoids and varicose veins. It is no longer used today. However, it is sometimes added to tea blends to improve the appearance of herbal teas. The use of flowers, seeds and roots in high doses causes gastroenteritis, colic and diarrhea. Paeonia roots (Radix paeoniae) are used as emetics and emmenagogue (Bisset, 1994).

According to Baytop (1994), its roots are used as a sedative. As a result of experiments on mice, no anti-inflammatory effect was found.

The roots of $P$. officinalis species Radix paeoniae contain a heteroside called peonol and has astringent and antispasmodic effects. It is used an infusion sedative in epilepsy and pertussis (Tanker et al., 2007).

In Eastern countries, especially in Egypt, Paeonia root is used against epilepsy by being passed on the patient's chest in the form of a cross. For this reason, this drug is called "Cross of the Cross" in Egypt. In old publications, it is recorded that it is beneficial to make incense with the fruits of this plant against the palace or to hang its root around the neck of the patient (Baytop, 1999). 
On the anti-inflammatory activity of P.peregrina and $P$. daurica species, although the methanol extract of $P$. daurica roots showed high anti-inflammatory activity compared to the standard aspirin, no significant activity was detected in $P$. peregrina roots. A study on the anti-inflammatory property of the roots of $P$. daurica species in Turkey has shown that folk medicine use of this plant is actually ready to replace drugs (Yeşilada et al., 1989; 1992).

Şener (1994) reported that the roots of $P$. daurica species had anti-inflammatory activity and concluded that it could be used instead of Moutan roots used in traditional Chinese medicine.

Orhan and Şener (2005), in their work on drug candidates of some plants in Turkey stated that anti-inflammatory activity was observed in the roots of $P$. daurica species.

Ethanol extract of Paeonia lactiflora roots at doses of 250 and $500 \mathrm{mg} / \mathrm{kg}$ oppesed reserpineinduced ptosis and low body temperature (hypothermia), while at a dose of $125 \mathrm{mg} / \mathrm{kg}$ it only opposed hypothermia, and a result, $P$. lactiflora species was clearly antidepressant (Mao et al. 2008).

6860 patients and 37046 Chinese herbal medicine samples were used in a 4-year study on drugs used in Chinese herbal medicine for insomnia. There were Carthamus tinctorius which was most prescribed and another blend containing Paeonia lactiflora in its Formula. Among the most commonly prescribed examples of Chinese herbs, P. suffruticosa (Mu Tan Pi) and P.lactiflora (Shuoh- Yaw) species are also found in the most widely used herbal mixtures. Herbal mixture known as Jia-Wey--Shiau-Yau-San, consisted of Angelica sinensis, Atractylodes macrocephala. Paeonia lactiflora. and Bupleurum chinense, Poria Cocos, is the most used in the regulation of menopausal symptoms. This mixture has been sought to relieve critical symptoms in women who often refuse hormone intake or develop contraindications after menopause (Chen et al., 2009).

Mao et al. (2009) exposed mice to chronic uncertain stress and investigated the effect of Paeonia glycosides on this stress. At the end of the study, it was stated that Paeonia glycosides alleviated this induced depression and this antidepressant-like effect occurs through inhibition of monoaminoxidases and reduction of oxidativestress in the mouse brain. Thus, it has been proven that the relationship between Paeonia and the healer Paeon has a medical.

Modern researchers have found a compound in Paeonia roots that was formerly thought to be alkaloid but acts as a glycoside, yielding oil known as paeonol and paeonine. This oil now has limited use even in Asian medicine. Western neuropathic and homeopathic practitioners mostly use flowers and seeds (Stearn et al., 1984; Halda et al., 2004).

In the book titled "Treatment with Plants in Turkey" it has been stated that peony roots has soothing properties, and used as a sedative against epileptic seizures and cough. It has also been stated that it contains tannin, essential oil, alkaloid and paeonol in its composition and that the infusion is used as drinking 2-3 glasses a day (Baytop, 1999). 
On the ethnobotanical research and evaluation of medicinal plants conducted in the Izmir region, it was noted that the roots of 14 P. mascula (L.) species were used as mouthwash against sore throats in the form of antihemorrhagic, antispasmodic, epilepsy, sedative, cough, whooping cough and tuberculosis (Ugulu et al., 2009).

In a study conducted in Adana and Mersin, the flowers and roots of P. mascula (L.) Miller (Şakayık, ayıülü, dede gülü) species contain tannin and essential oils and purgative, stomachic, collagog, hepatoprotective. They stated that it is used in urinary system diseases, in the treatment of jaundice and as a hemagogue in the form of douching or direct application. The P. mascula species is known as the local 'ayıülü' in Kahramanmaraş and its roots are used as sedative, epilepsy and cough treatment and as a respiratory regulator (Karaman et al., 2001; Everest and Öztürk, 2005).

In a study conducted in Ovacık town of Tunceli Province, Turkey, Doğan (2008) stated that the infusion prepared from the young above-ground parts of P. mascula subsp. arietina drunk on an empty stomach to reduce blood sugar and its young above ground parts could be used in the treatment of diabetes.

The type of $P$. mascula subsp is known as 'ayıülü' in Turkey and its roots are used as an infusion in sedatives, antitussives and epilepsy (Fakir et al., 2009).

Ding et al. (2000) examined the effects of chemical compounds isolated from the roots of Chinese Paeonia suffruticosa. They reported that they play an important inhibitory role against platelet aggregation with hemorrhage and inflammation caused by bacterial infection.

In a study conducted in Turkey, Paeonia daurica obtained from Mesudiye town of Ordu province showed antimicrobial activity against Gram (-) bacteria, Gram (+) bacteria, mycobacterium and fungi (Tosun et al., 2011).

Picerno et al. (2011), investigating the free radical scavenging and antifungal effects of dried roots of Paeonia rockii, reported that methanol extract of the roots free radical scavenging and antifungal effects.

In a study on plants used in the treatment, it has been reported that Paeonia mascula L. Miller subsp. Arietina (Anders) type is used in the treatment of asthma (Melikoğlu et al., 2015).

Paeonia mascula L. Miller subsp. Arietina (Anders) in the form of decoction was also reported to be used in the treatment of diabetes in Eastern Anotolia (Arituluk and Ezer, 2012).

The antiamnesic activity of the ethanolic extract of the P. lactiflora (Paeoniaceae) subtype, which is reported to be used against amnesia in traditional Chinese medicine was measured in vitro, it was concluded that this traditional treatment was confirmed by the study conducted by Sevim et al. (2011). 
Some previous studies reported that hydroxyl and olefinic groups from resveratrol and other stilbene derivatives obtained from the leaves of $P$. lactiflora play significant antioxidant activity (Kim et al., 2002; Orhan et al., 2010).

In an in vitro study investigating the endothelium-dependent vasodilatation effect of extracts obtained from Paeonia lactiflora roots in isolated rat aortas, it was found that the main active components Paeoniflorin and Paeonol did not show vasodilatory effect, while some components showed endothelium-dependent vasodilator activity (Goto, 1996). In another study, it was observed that the components of both P. lactiflora and P. suffruticosa increased blood flow by inhibiting blood coagulation and platelet aggregation (Koo, 2010).

Paeonia lactiflora Pall has been used for over 1200 years in traditional Korean, Japanese and Chinese medicine. It is used in the treatment of fever, muscle cramps and spasms, rheumatoid arthritis, systemic lupus, dysmenorrhea, hepatitis. Pain relief has also been demonstrated in various animal models. In animal models of acute and subacute inflammation, its direct anti-inflammatory effect has been demonstrated by suppressing the increase in intracellular calcium ion concentration and inhibiting the production of nitric oxide, leukotriene B4 and prostaglandin (He et al., 2011). In another study, it was observed that $P$. lactiflora prevented itching and exhibited antiallergic effect in mice (Bomi et al., 2008).

Lee et al., (2006) evaluated the antiviral effect of the solvent prepared from the roots of the species of P. lactiflora Pall. in tissue culture system. The ethylacetate fraction showed strong antihepatitis b activity. However, other fractions showed no inhibition at the HBV DNA level.

In addition, Himalayan Peony (Paeonia emodi Royle) has been reported to be effective against epilepsy in traditional medicine for a long time (Miyazawa et al., 1984; Kirby and Schmidt, 1997; Verma et al., 2015).

\section{Conclusion}

With the increasing interest in phytotherapy in Turkey and in the world, the economic market value is also growing. It is thought that by determining the species present in the rich flora and investigating the possibilities of use in phytotherapy, we can bring beneficial returns to our country in terms of health and economy. With this review, it is aimed to draw attention to the peony plant, which has an important commercial ornamental potential and various species are used in phytotherapy. The plant is likely to be one of the important plants of the future. 


\section{Authors' Contributions}

All authors contributed equally to the study.

\section{Statement of Conflicts of Interest}

There is no conflict of interest between the authors.

\section{Statement of Research and Publication Ethics}

The author declares that this study complies with Research and Publication Ethics.

\section{References}

Anonymous. (2018). Determination of the problems encountered in the protection of medicinal and aromatic plant diversity, their production and marketing, and the measures to be taken. https://www.tbmm.gov.tr/develop/owa/genel_kurul.cl_getir?pEid=72598 (Access date: 09.10.2020).

Anonymous. (2020). https://www.trt.net.tr/vizyondergisi/vizyon-dergisi-nisan-2016/ (Access date:08.10.2020).

Arıtuluk, Z. C., Ezer, N. (2012). Plants used against diabetes among people. Hacettepe University Faculty of Pharmacy Journal, 32(2), 179-208.

Avcı, M. (2005). Çeşitlilik ve endemizm açısından Türkiye'nin bitki örtüsü. Coğrafya Dergisi, Sayı 13, 2855.

Baytop, T., (1994). Turkish plant names dictionary. Ankara: Atatürk High Institution of Culture, Language and History - Turkish Language Association Publications.

Bomi LeeYong-Wook ShinEun-Ah BaeSan-Jun HanJoo-Sun KimSam-Sik KangDong-Hyun Kim. (2008). Antiallergic effect of the root of Paeonia lactiflora and its constituents paeoniflorin and paeonol. Archives of Pharmacal Research, 31(4), 445-450.

Baytop, T. (1999). Türkiye'de Bitkiler ile Tedavi. 2. Baskı. İstanbul: Nobel Tip Kitabevleri Ltd. Şti. Tayf Ofset Bask1.

Bisset, N. G., Wichtl, M. (1994). Herbal drugs and phytopharmaceuticals. Stuttgart: Medpharm Scientific Publishers. 566 pages.

Chen, L.-C., Chen, I.-C., Wang, B.-R. \& Shao, C.-H. (2009). Drug-use pattern of Chinese herbal medicines in insomnia: a 4-year survey in Taiwan. Journal of Clinical Pharmacy and Therapeutics, 34, 555560.Davis, P.H. (1965). Flora of Turkey and the East Aegean Islands. Vol. 1, Edinburgh: University Press.

Davis, P.H. (1965). Flora of Turkey and the east Aegean islands. Vol. 1, Edinburgh: University Press.

Ding, H. Y., Lin, H. C., Teng, C. M., Wu, Y. C. (2000). Phytochemical and pharmacological studies on Chinese Paeonia species. Journal of the Chinese Chemical Society, 47(2), 381-388.

Doğan, A. (2008). Ovacık (Tunceli) yöresinin geleneksel halk ilacı olarak kullanılan bitkileri. Yüksek Lisans Tezi, Marmara Üniversitesi, Eczacılık Fakültesi Farmasötik Botanik Anabilim Dalı. İstanbul.

Donner, J. (2007). Turkey's plant distribution maps. Istanbul: Lazer Ofset Matbaa Tesisleri San. ve Tic. Ltd. Şti.

Everest, A., Öztürk, E. (2005). Focusing on the ethnobotanical uses of plants in Mersin and Adana provinces (Turkey). Journal of Ethnobiology and Ethnomedicine, 1, 1-6.

Fakir, H., Korkmaz, M. \& Güler, B. (2009). Medicinal plant diversity of Western Mediterrenean Region in Turkey. Journal of Applied Biological Sciences, 3(2), 30-40. 
Friedman, J. M. 2000. Teratology society: presentation to the FDA public meeting on safety issues associated with the use of dietary supplements during pregnancy. Teratology, 62, 134-7.

Goto, H., Shimada, Y., Akechi, Y., Kohta, K., Hattori, M., and Terasawa, K. (1996). Endothelium-dependent vasodilator effect of extract prepared from the roots of Paeonia lactiflora on isolated rat aorta. Planta Med., 62(5), 436-439.

He. D. Y., Dai S. M. (2011). Anti-inflammatory and immunomodulatory effects of Paeonia lactiflora Pall., A traditional Chinese herbal medicine. Front Pharmacol. Feb 25; 2: 10. doi: 10.3389 / fphar.2011.00010. PMID: 21687505; PMCID: PMC3108611.

Halda, J. J., Waddick, J. W. (2004) The Genus Paeonia. (Second Edition). Timber Press, 2010. 227 pages.

Izzo, A. A, Di Carlo, G, Borrelli, F, Ernst, E. (2005). Cardiovascular pharmacotherapy and herbal medicines: the risk of drug interaction. Int J Cardiol. 98, 1-14.

Karaman, Ş. \& Kocabaş, Y. Z. (2001). Traditional medicinal plants of K. Maras (Turkey). The Sciences, 1(3), 125-128.

Kaya, E. (2016). Türkiye biyoçeşitliliğinde geofitlerin yeri ve bazı çalışmalar. TÜRKTOB magazine, 18: 6979.

Kirby, A. J. and Schmidt R, J. J. (1997). The antioxidant activity of Chinese herbs for eczema and of placebo herbs. Ethnopharmacol., 56, 103-108.

Koo Y. K., Kim J. M., Koo J. Y., Kang S. S., Bae K, Kim Y. S., Chung J. H., Yun-Choi H. S. (2010). Platelet anti-aggregatory and blood anti-coagulant effects of compounds isolated from Paeonia lactiflora and Paeonia suffruticosa. Pharmazie, 65(8): 624-8.

Kim, H. J., Chang, E. J., Cho, S. H., Chung, S. K., Park, H. D., Choi, S. W. (2002). Antioxidative activity of resveratrol and its derivatives isolated from seeds of Paeonia lactiflora. Bioscience, Biotechnology, and Biochemistry, 66(9). 1990-1993.

Karagöz, A., Zencirci, N., Tan, A., Taşkın, T., Köksel, H., Sürek, M., Toker, C. and Özbek, K. 2010. Conservation and use of plant genetic resources. TMMOB Chamber of Agricultural Engineers, Agricultural Engineering 7th Technical Congress, p: 155-177, 11-15 January 2010, Ankara.

Kaya, E. 2010. Türkiye şakayıklarının (Paeonia Spp.) kültüre alınması ve 1slahı. IV. Süs Bitkileri Kongresi. Erdemli, Mersin. 22-22 Ekim. 2010.

Lee, S. -J., Lee, H. -K., Jung, M. -K. \& Mar, W. (2006). In vitro antiviral activity of 1, 2, 3, 4, 6-penta-Ogalloyl-b-D-glucose against hepatitis B virus. Biological \& Pharmaceutical Bulletin, 29(10), 21312134.

Mao, Q., Huang, Z., Ip, S., Che, C. (2008). Antidepressant-like effect of ethanol extract from Paeonia lactiflora in Mice. Phytotherapy Research, 22, 1496-1499.

Mao, Q. -Q., Ip, S. -P., Ko, K. -M., Tsai, S. -H., Xian, Y. -F. \& Che, C. -T. (2009). Effects of peony glycosides on mice exposed to chronic unpredictable stress: Further evidence for antidepressant-like activity. Journal of Ethnopharmacology, 124, 316-320.

Melikoğlu, G., Kurtoğlu, S., and Kültür, Ş. (2015). Plants traditionally used in asthma treatment in Turkey. Marmara Pharmaceutical Journal, 19: 1-11.

Miyazawa, M., Maruyama, H., Kameoka, H. (1984). Essential oil constituents of "MOUTAN RADIOS CORTEX" Paeonia moutan Sims. (= P. suffruticosa Andrews). Agricultural and Biological Chemistry, 48(11), 2925-2927.

Nathan M, Scholten R. (1999). The Complete German Commission E Monographs: Therapeutic guide to herbal medicines. Annals of Internal Medicine. 130(5), pp 459.

Orhan, I., Şener, B., (2005). Discovery of drug candidates from some Turkish plants and conservation of biodiversity. Pure Appl. Chem., 77(1), 53-64.

Orhan, I., Demirci, B., Omar, I., Siddiqui, H. (2010). Essential oil compositions and antioxidant properties of the roots of twelve Anatolian Paeonia taxa with special reference to chromosome counts. Pharmaceutical Biology, 48(1), 10-16.

Özhatay, N., Koyuncu, M., (1998). New trends and methods in natural products Research's, 11-38.

Picerno, P., Mencherini, T., Sansone, T., Gaudio, P. D., Granata, I., Porta A., Rita P. (2011) Screening of a polar extract of Paeonia rockii: Composition and antioxidant and antifungal activities. Journal of Ethnopharmacology, 138(3), 705-712.

Sert E, Sert, A, Kalaycı, M. Z., Sakarya, A. A., Yüksel, Ş. B. (2015). The place of phytotherapy in oral and dental health. Integr Medical Derg. 3, 35-40.

Sarışen Ö, Çalışkan D. (2005). Phytotherapy: attention to treatment with herbs. Sted Magazine, 14/8: 182-7.

Sener, B. (1994). Recent results in the search for bioactive compounds from Turkish medicinal plants. Pure and Applied Chemistry, 60, 2295-2298. 
Stearn, W. T., Davis, P. H. (1984). Peonies of Greece: A taxonomic and historical survey of the genus Paeonia in Greece. The Goulandris Natural History Museum, Kifissia, Greece; 1st Edition.

Sevim, D., Senol, F. S., Orhan, I., Şener, B., Kaya, E. (2011). Anti-amnesic activity screening of the seed ethanol extracts of Turkish Paeonia taxa by in vitro methods. Planta Med., 77 - PM166.

Tosun, G., Kahriman, N., Gulec Colonel, C., Alpay Karaoglu, Ş., Yayl1, N. (2011). Antimicrobial activity and volatile constituents of the flower, leaf, and stem of Paeonia daurica grown in Turkey. Turk J Chem, $35,145-153$.

Tanker, N., Koyuncu, M. \& Coşkun, M. (2007). Farmasötik Botanik. Ankara: Ankara Üniversitesi Eczacılık Fakültesi Yayınları.

Tuzlac1, E. (2006). Turkey Plant Dictionary. Istanbul: Alfa Publishing Distribution Ltd. Şti.

Ugulu, I., Baslar, S., Yorek, N. \& Doğan, Y. (2009). The investigation and quantitative ethnobotanical evaluation of medicinal plants used around Izmir province, Turkey. Journal of Medicinal Plants Research, 3(5), 345-367.

Uyanık, M., Kara, M., Gürbüz, B., Özgen, Y. (2013). Türkiye'de bitki çeşitliliği ve endemizm. Ekoloji Sетроzуити, Tekirdağ, 2013. S. 197.

Ünlü, S., 2010. Türkiye'nin Paeonia L. türleri üzerinde farmasötik botanik araştırmalar. Yüksek Lisans Tezi.

Verma, R. S., Padalia R. C., Chauhan, A. (2015). Essential oil composition of Himalayan Peony (Paeonia emodi Royle), Journal of Essential Oil Research, 27(6): 477-480.

Yeşilada, E., Mutlugil, A., Şener, B. (1992). The Antiinflammatory principle of the roots of Paeonia daurica . Int. J. Pharmacognosy, 30(1), 66-70.

Yeşilada, E., Mutlugil, A., Şener, B. \& Sezik, E. (1989). Paeonia daurica Andrews ve P. peregrina Miller'nın antieflamatuar aktivitesi. VIII. Bitkisel İlaç Hammaddeleri Toplantısı (İstanbul, 19-21 Mayıs 1989) Bildiri Kitabı. Cilt II. İstanbul: İ. Ü. Basımevi ve Film Merkezi; 361-364. 